\title{
Tau and DNA Damage in Neurodegeneration
}

\author{
Luca Colnaghi ${ }^{1, *}$, Diego Rondelli ${ }^{2}$, Marco Muzi-Falconi ${ }^{2}$ and Sarah Sertic ${ }^{2, *}$ (i) \\ 1 Department of Molecular Biochemistry and Pharmacology, Istituto di Ricerche Farmacologiche Mario Negri \\ IRCCS, Via Negri 2, 20156 Milan, Italy \\ 2 Dipartimento di Bioscienze, Università degli Studi di Milano, Via Celoria 26, 20133 Milan, Italy; \\ diego.rondelli@unimi.it (D.R.); marco.muzifalconi@unimi.it (M.M.-F.) \\ * Correspondence: luca.colnaghi@marionegri.it (L.C.); sarah.sertic@unimi.it (S.S.)
}

Received: 16 October 2020; Accepted: 2 December 2020; Published: 7 December 2020

\begin{abstract}
Neurodegenerative disorders are a family of incurable conditions. Among them, Alzheimer's disease and tauopathies are the most common. Pathological features of these two disorders are synaptic loss, neuronal cell death and increased DNA damage. A key pathological protein for the onset and progression of the conditions is the protein tau, a microtubule-binding protein highly expressed in neurons and encoded by the MAPT (microtubule-associated protein tau) gene. Tau is predominantly a cytosolic protein that interacts with numerous other proteins and molecules. Recent findings, however, have highlighted new and unexpected roles for tau in the nucleus of neuronal cells. This review summarizes the functions of tau in the metabolism of DNA, describing them in the context of the disorders.
\end{abstract}

Keywords: tau; DNA damage; Alzheimer's disease

\section{Introduction}

Neurodegeneration is the gradual degeneration and death of neurons in the central or peripheral nervous systems [1]. Alzheimer's disease (AD) is among the most common neurodegenerative diseases, and this debilitating and incurable condition is rapidly becoming even more common with the aging of the population [2]. Although the cause of AD is still not clear, its onset and progression correlate with levels of hyperphosphorylated and aggregated tau [3-9].

Tau is a microtubule-associated protein (MAP) encoded by the MAPT gene [10]. In healthy adult subjects, tau is a soluble, non-hyperphosphorylated protein that can promote the self-association of tubulin into microtubules [11-13]. Humans express six tau isoforms, all derived from alternative mRNA splicing of the MAPT gene. In neurons, all isoforms are mainly localized in axons; they are natively unfolded and can bind and interact with the microtubule [11,14-17]. Tau isoforms interact with other proteins and with nucleic acids besides the microtubule [18,19].

In $\mathrm{AD}$, tau is abnormally phosphorylated by numerous kinases at several sites [20]. Hyperphosphorylated tau is the principal component of neurofibrillary tangles (NFTs), a pathological hallmark of AD that correlates with severity of dementia [21,22]. Although the role of the hyperphosphorylation of tau is debated [23], a leading hypothesis suggests that the aberrant phosphorylation is required to induce aggregation of the protein to form tau oligomers and NFTs [23]. While NFTs can be formed by wild-type tau [24], tau mutants often have a reduced ability to bind the microtubule and a higher propensity to be insoluble and form NFTs $[25,26]$. Tau NFTs are also found in other neurodegenerative disorders, such as frontotemporal dementia, progressive supranuclear palsy, corticobasal degeneration and Pick's disease, collectively called tauopathies $[27,28]$. While tau pathology is at the base of all these conditions, the structures of tau aggregates and filaments that can be found in these disorders vary [6-9]. Overall, this evidence suggests a predominant role of 
tau hyperphosphorylation and aggregation in the onset and progression of AD and a promising pharmaceutical target [29,30]. A second pathological marker of AD are extracellular amyloid- $\beta$ plaques $(A \beta)$. Their role in AD is still debated, since their presence does not correlate with AD onset and progression [31]. However, some species of $A \beta$ oligomers are toxic to neurons, can induce neurodegeneration and may be a valid therapeutic target for AD [31-33].

Several types of post-translational modification have been described for tau, phosphorylation being the most studied [34]. This is because abnormally and hyperphosphorylated tau has been found in tau NFTs purified from AD patients. Although tau phosphorylation and deposition correlate with neurodegeneration, the mechanisms responsible for tau toxicity are still unclear $[35,36]$. This has led to therapies with limited efficacy and tauopathies are currently untreatable.

In the past decade, new and unexpected roles of tau have emerged in the nucleus and in the maintenance of genome stability [19,37]. These findings are supported by the fact that DNA lesions are recurrent in post-mortem brains of subjects with neurodegenerative diseases [38,39].

Maintaining the integrity of the genome is crucial for the physiology of any nucleated cell [40]. Our genome can, however, be attacked by endogenous and exogenous sources that can induce DNA damage. If not properly repaired, DNA lesions may cause mutations, altering cellular processes or leading to cell death [41]. Research on DNA repair mechanisms has mainly focused on cycling cells, in view of the high incidence of DNA mutations and chromosomal rearrangements in proliferating cancer cells [42]. These studies have shown that mammalian cells have developed several specific pathways to recognize and repair DNA lesions and collectively they constitute the DNA damage response (DDR) [43]. The importance of a functional DDR is illustrated by the many cancer susceptibility disorders caused by DNA repair deficiencies such as ataxia-telangiectasia, xeroderma pigmentosum, Nijmegen breakage syndrome, Bloom syndrome, Werner syndrome and many others [44-46].

The nature of DNA damage that the genome can develop varies widely and to face this variety, cells utilize several repair mechanisms, each specialized in a different type of DNA lesion. In mammals, at least five major DNA repair pathways safeguard the genome (Figure 1) and they not only act on the metabolism of DNA, but also modulate cell cycle checkpoint proteins to affect cell cycle progression [47]. The major repair pathways are base excision repair (BER), mismatch repair (MMR), nucleotide excision repair (NER) and DNA double-strand break (DSB) repair, mediated by homologous recombination (HR) and/or nonhomologous end joining (NHEJ) [47]. BER is the main pathway for the repair of damaged DNA bases that do not significantly distort the structure of the DNA helix, such as oxidized nucleotides [48]. There are two general BER pathways: short-patch and long-patch BER. The former leads to repair of a tract of a single nucleotide and the latter to a tract of at least two nucleotides. The MMR pathway is mainly involved in the repair of misincorporated nucleotides that have been inserted by the replicative polymerases [49]. NER can recognize and remove different types of bulky and helix-distorting lesions from DNA. There are two NER pathways: transcription coupled-NER, which removes bulky lesions formed on transcribed sequences, and global genome-NER to remove distorting lesions in the whole genome [50]. HR and NHEJ are specialized pathways that repair DNA DSBs [43].

DSBs are considered to be amongst the most dangerous types of DNA damage. In mammals, a single unrepaired DSB can lead to cell death [51], and errors in their processing may cause deletions or chromosomal aberrations, which, in turn, can trigger the development of cancer or other genomic instability disorders [52]. Thus, DSB repair is critical for cell survival and the maintenance of genomic integrity. HR [53] and NHEJ [54] differ in their requirement for a homologous template DNA and the fidelity of DSB repair. HR repairs lesions in an error-free fashion, since it uses the undamaged sister chromatid as a template. It is therefore restricted to the late $S$ and G2 phases of the cell cycle [52]. NHEJ, on the other hand, is more error-prone, and repairs DSBs by direct ligation of the broken ends, with minimal processing. NHEJ is believed to be active in all phases of the cell cycle [54].

While all these DDR pathways are functional in proliferating cells, profound differences in DNA repair mechanisms have been reported for postmitotic cells such as neurons [55-57]. The onset and 
role of DNA lesions in AD and their connection with tau pathology are not clear (Figure 1, red column). The aim of this review is therefore to describe the latest findings that may link tau and/or pathological tau to DNA lesions and neurodegenerative processes in tauopathies.

\begin{tabular}{|c|c|c|c|}
\hline $\begin{array}{r}\text { DNA DAMAGING } \\
\text { AGENTS }\end{array}$ & $\begin{array}{l}\text { DNA } \\
\text { LESION }\end{array}$ & $\begin{array}{l}\text { DNA REPAIR } \\
\text { PATHWAY }\end{array}$ & IN AD \\
\hline $\begin{array}{r}\text { lonizing radiations } \\
\text { X-rays } \\
\text { Drugs }\end{array}$ & $\begin{array}{l}\text { Double strand breaks } \\
\text { Single strand breaks } \\
\text { Interstrand crosslinks }\end{array}$ & $\begin{array}{l}\text { Double Strand } \\
\text { Break Repair } \\
\text { (DSBR) }\end{array}$ & $\begin{array}{l}\text { Lower levels of BRCA1 and } \\
\text { mislocalization to cytoplasm }\end{array}$ \\
\hline $\begin{array}{l}\text { UV-light } \\
\text { Chemicals }\end{array}$ & $\begin{array}{l}\text { Pyrimidine dimes } \\
\text { Bulky adducts } \\
\text { Intrastrand crosslinks }\end{array}$ & $\begin{array}{l}\text { Nucleotide } \\
\text { Excision Repair } \\
\text { (NER) }\end{array}$ & $?$ \\
\hline $\begin{array}{r}\text { Oxygen radicals } \\
\text { Hydrolysis } \\
\text { Alkylating agents }\end{array}$ & $\begin{array}{l}\text { Abasic sites } \\
\text { Single strand breaks } \\
\text { 8-oxoguanine }\end{array}$ & $\begin{array}{l}\text { Base Excision } \\
\text { Repair } \\
(B E R)\end{array}$ & $\begin{array}{l}\text { Lower 8-oxoguanine glycosylase } \\
\text { activity, Downregulated } \\
\text { Pol } \beta \text { expression }\end{array}$ \\
\hline Replication errors & Bases mismatched & $\begin{array}{l}\text { MisMatch Repair } \\
\text { (MMR) }\end{array}$ & $?$ \\
\hline
\end{tabular}

Figure 1. Types of DNA lesions, their DNA repair pathways and possible connections with Alzheimer's Disease (AD). The principle and well-characterized DNA damage repair pathways are double-strand break repair (DSBR), nucleotide excision repair (NER), base excision repair (BER) and mismatch repair (MMR). DSBR- and BER-specific mutations have been associated with AD (red).

\section{Neurons and the Repair of DNA Lesions}

Neurons are the longest-living postmitotic cells in the human body [58]. To function for decades, they have to safeguard their genomes from endogenous and, to a lesser extent, exogenous DNA insults [55]. The main threat to their genomes comes from endogenous sources in the forms of (i) cytotoxic reactive oxygen species (ROS) that can cause oxidative DNA damage, and (ii) activity-dependent transcription that induces DSBs [59,60]. Exogenous sources are curbed by the blood brain barrier (BBB), which spares brain cells from the majority of the exogenous DNA insults, limiting, therefore, the possible sources of DNA lesions [61]. Nevertheless, a handful of chemicals, such as the common carcinogen benzo[a]pyrene, can pass the BBB and cause DNA lesions [62].

Oxidized DNA is believed to be the most common DNA lesion in neurons. This is unavoidable due to their high metabolic activity [63]. The BER pathway is therefore probably the most active DDR mechanism in neuronal cells. Similarly, to cycling cells, in neurons, the oxidized nucleotide is recognized and removed by a DNA glycosylase that starts BER and generates an abasic site. The lesion is further processed by short-patch or long-patch repair to complete BER [48].

Aside from oxidized DNA, a second major threat to neuronal genomes comes from DNA DSBs arising from the development and plasticity of the brain. Neuronal activity triggers the expression of immediate early genes, usually transcription factors, which mediate neuronal physiology by regulating the expression of several downstream targets. To ensure fast activation of immediate early genes, neurons resolve DNA topological constraints in their promoters by breaking the double helix. The creation and repair of the resulting DNA DSBs are apparently mediated by topoisomerase II $\beta$ (Topo II $\beta$ ) and can be visualized by the detection of histone $\gamma \mathrm{H} 2 \mathrm{AX}$ foci, a general marker of DNA DSBs $[60,64]$. However, inhibition of the DNA-dependent protein kinase (DNA-PK), a required component in the activation of NHEJ [65-67], prevents the repair of activity-induced DSBs, thus suggesting a more complex mechanism of repair of these breaks, where the role of NHEJ is still unclear [64]. Sleep, a state characterized by a decline in neuronal firing, has been proposed as required 
to reduce the number of DSBs in single neurons $[68,69]$. This suggests somehow that DNA repair is facilitated in resting state neurons.

Initial interest in neuronal DNA repair however did not stem from physiological processes but from the neurological defects observed in several inherited conditions, where mutations in DNA repair genes caused premature neuronal death. Examples are conditions such as xeroderma pigmentosum (an autosomal recessive genetic disorder in which NER is aberrant), Cockayne's Syndrome (another condition belonging to the NER-related family of disorders) and ataxia-telangiectasia syndrome (with mutations in the Ataxia Telangiectasia Mutated (ATM) apical kinase) [70]. There is thus overwhelming evidence that genome maintenance is as important in neurons as in all other tissue cells. In addition, like in other somatic cells, DNA repair in these highly specialized cells is not without mistakes. Unfaithful DNA repair has been confirmed by recent single-cell whole-genome sequencing, proposing that with time, neurons accumulate somatic mutations [71,72]. This suggests that genomic instability in neurons may be a part of normal aging. Whether this is also at the basis of neurological disorders, and whether tau has any role in this, is still not clear.

\section{Neurodegeneration and DNA Lesions}

The pathophysiology of tauopathies, including AD, consists of synaptopathy, changes in neurotransmitter expression, accumulation of intracellular tau NFTs, neuronal loss and brain atrophy [2,73]. Accumulation of unrepaired DNA is another feature of AD [74], while for other tauopathies it has been only briefly explored [38,39,75-78]. The lesions are likely caused by ROS produced by $\mathrm{A} \beta$ and tau oligomers, and their onset is accompanied by the activation of DDR kinases, such as ATM, that can phosphorylate a plethora of targets $[79,80]$.

Compared to age-matched controls, histone $\gamma \mathrm{H} 2 \mathrm{AX}$-positive neurons are increased in the hippocampus and frontal cortex of subjects suffering from mild cognitive impairment or AD [74,81]. This suggests there may be more DSBs in the genome of those neurons. Mild cognitive impairment is a preclinical stage of AD, and the presence of DNA DSBs can suggest a role of DNA lesions in the early stages [82]. DNA DSBs are not, however, the only DNA lesions described in the literature. DNA single strand breaks (SSBs) are also reported in the hippocampi of AD brains [39]. Among the likely causes of SSBs and DSBs, the majority of DNA lesions in neurons are caused by ROS. Nuclear and mitochondrial DNA derived from brain cells of subjects with reported neurodegenerative diseases contain more oxidative DNA lesions, detected by 8-hydroxy-2'-deoxyguanosine (8-OHdG), a widely used marker of DNA oxidation [83-85]. However, it is still debated why these DNA lesions accumulate in AD and cause DNA SSBs and DSBs, but it could in part be due to a reduction in their repair. 8-Oxoguanine glycosylase activity is lower in AD than controls [86] and the expression of POL $\beta$, the main DNA polymerase involved in BER, is also downregulated (Figure 1, red). This can also be seen in mild cognitively impaired subjects [86].

Along with proteins belonging to BER, other DDR genes are reported to be affected in AD. ATM is reduced in the frontal cortex of AD brains and also downregulated in mouse models of AD [80]. Evidence from human AD samples and animal models suggests that NHEJ is affected in AD pathology $[87,88]$.

DNA DSBs formation may also depend on the physiological activity of neurons in the pathological context of AD [60]. Following activity, DNA DSBs were increased by exposure to amyloid- $\beta$ oligomers [60]. This increase may be linked to the ability of $A \beta$ to lower the levels of the DNA repair protein BRCA1 and the activity of DNA-PK $[89,90]$. All this suggests a direct link between neuronal activity, DNA lesions and a pathological marker of AD. Tau ablation reduced A $\beta$ effects on DSBs in neurons [60], but the role of tau oligomers in activity-dependent DNA DSBs in AD has not been explored.

BRCA1, a critical regulator of DNA repair, cell cycle checkpoint control and maintenance of genomic stability, may also have a role in AD. In neurons, its protein levels are regulated by neuronal activity and seem to be low in the brains of AD patients $[90,91]$. In vitro, A $\beta$ oligomers reduced the 
levels of BRCA1 in primary neuronal cultures [90]. Apart from its expression, the localization of BRCA1 also seems to be affected by AD. In neurons from young familial AD subjects, BRCA1 shows cytosolic localization and phosphorylation after DDR activation [92]. In the cytosol, BRCA1 co-localizes with presenilin 1 (PS1) [91], a component of a multi-subunit protease that targets the amyloid precursor protein (APP) to make A $\beta$. Mutations in the gene encoding PS1 are the most common cause of familial AD [93], thus strongly linking BRCA1 with the pathology. BRCA1 may also have a role in sporadic AD. The protein was phosphorylated in post-mortem brains of sporadic AD patients positive to $A \beta$ plaques [94].

\section{Neurodegeneration, Cell Cycle Regulation and DNA Damage}

Neurons, once they differentiate, cannot proliferate [58]. This seems to be due to cell cycle suppression, an active process that restrains cell cycle progression. In vivo and in vitro data indicate that various insults can loosen these restraints, pushing neuronal cells to re-enter the cell cycle, and cell death. Originally it was thought that when cell cycle progression restarts, neurons reach the G1/S boundary and cell death occurs by apoptosis before new DNA synthesis [95]: a process regulated by CDKs (Cyclin Dependent Kinase), transcription factors and effectors of the DNA damage checkpoint such as ATM and the tumor suppressor p53 [96]. However, there are exceptions. During development, for instance, some neurons re-enter the cell cycle, replicate their DNA and reach the G2/M transition as tetraploid cells where they stop proliferating; mitosis never takes place and these remain viable [97,98]. The reason why some neurons become polyploid is currently debated. In healthy neurons, re-entry into cell cycle progression and passing the G2/M boundary is very rare, and usually leads to the death of these neurons [58,99].

A connection between neurodegeneration and cell cycle re-entry was proposed when phosphorylated forms of tau, normally found in cycling cells, were identified in neurons from AD patients. This led to discovering that the percentage of neurons that reactivate their cell cycle is doubled in AD. Neuronal DNA replication has been extensively documented in AD, suggesting progression past the G1/S boundary [77,100]. More likely, therefore, in AD, neurons can reach the G1/S boundary, replicate their DNA and successfully enter G2 as tetraploid neurons. Mitosis, however, is very rare, and neurons block their cell cycle at the G2/M transition and can survive for years [96,101-104]. The reason for this is also still not clear. A leading hypothesis suggests, however, that DNA lesions and their repair may have a role. During neurodegenerative processes, unrepaired DNA lesions may push the cells to re-enter cell cycle progression $[105,106]$. This evidence comes from i) the description of cell cycle restarts in early neurodegenerative processes $[107,108]$ and ii) AD patient specimens that have higher levels of cell cycle protein expression than healthy controls [100]. The presence of tetraploid neurons in the cerebral cortex is an early sign of AD [101]. This is seen in the absence of tau NFT, suggesting that tetraploidy may precede the neuropathological signs of AD [109]. How, in AD, neurons reactivate their cell cycle and replicate their DNA and whether tau has any role in this is still debated, but it is worth noting that cyclin-dependent kinase inhibitors are neuroprotective [110].

\section{Tau and DNA Lesions}

Although tau is primarily considered a cytosolic protein, it is reported to interact with nucleic acids and to localize to the nucleus of neuronal and non-neuronal cells [37,111-114]. In neurons, tau in the nucleus is hypophosphorylated [19], evidence supported also by studies in neuroblastoma SH-SY5Y cells [115]. In vitro, tau binds the minor groove of the DNA double helix and interacts with single-stranded DNA with less affinity [116,117]. Hyperphosphorylation of tau reduces its ability to bind DNA [118]. Purified tau has higher affinity for DNA than microtubules [119]. The DNA-tau complex shares some structural similarities with the DNA-histones complex and may efficiently preserve DNA [117,120,121]. For instance, the binding protects DNA from ROS, such as hydroxyl radicals, and also raises the melting temperature of the double helix [116,117,122]. The interaction between tau and DNA can also affect tau's biochemical properties, facilitating its aberrant aggregation. 
DNA, being a polyanionic molecule, may trigger protein misfolding and insolubility [123]. Interestingly, the DNA of bacteria may be more prone to this than the DNA of eukaryotic cells [124], somehow supporting a positive association between bacterial infection and AD [125,126]. Whether viral DNA has any effects on tau aggregation is still not clear. Nevertheless, viral infection can relocate tau to the nucleus [127].

In cultured murine primary neurons, tau binds chromatin in physiological conditions, showing a preference for Adenine and Guanine (AG_-rich regions. This interaction is dynamic and can be modulated under stress conditions [128]. In cells, tau quite likely participates directly in DDR in response to DNA lesions. In the absence of tau, cells have increased phosphorylation of histone $\mathrm{H} 2 \mathrm{AX}$ on serine 139 ( $\gamma \mathrm{H} 2 \mathrm{AX}$ ) [129], suggesting more DNA lesions or a longer DNA repair time. Although the mechanism is not fully understood, the main evidence to suggest that tau regulates genomic stability in neurons comes from primary cultures of tau knock-out neurons subjected to heat shock. Hyperthermic conditions trigger the production of ROS that, in turn, can damage the DNA [130]. Compared to wild-type neurons, the cellular stress induces DNA breaks that can be prevented by expression of human tau targeted to the nucleus [19]. This protective mechanism is likely also present in vivo. In the hippocampus and cortex of tau knock-out mice, hyperthermia induces DNA DSBs and histone H2AX phosphorylation [129]. Tau deletion also caused a slower repair of DNA DSBs in the hippocampus of the animals [129], thus suggesting both a DNA protective role and a direct or indirect DNA repair role of tau in the brain. Other than by binding to the DNA, tau can also safeguard the genome indirectly. It can bind the mitotic spindle microtubules, probably similarly to its interaction with the cytoskeleton, to stabilize it [131]. An unstable mitotic spindle can cause chromosomes to mis-segregate and can lead to chromosomal instability [132]. Along this line, peripheral cells of patients with mutated tau present chromosomal aberrations [131,133]. This is further supported by (i) an increase in chromosomal aberrations in tau knock-out mice and (ii) a higher risk of cancers, besides tauopathies, in families carrying tau mutations [133,134]. Tau deletion also affects nuclear organization by affecting heterochromatin and DNA methylation in cultured neurons. The absence of tau causes a surge of DNA breaks in these regions, a finding confirmed in AD patient-derived samples [135,136]. This evidence suggests that (i) tau can maintain genomic stability and that (ii) DNA lesions in AD and tau may be linked (Figure 2). In non-neuronal cells, tau has been proposed to directly affect DNA repair by interacting with p53, Pin1 and PARN by modulating nuclear de-adenylation following UV-induced DNA damage. Further experiments are needed to determine whether this mechanism is present also in neurons and whether it may be relevant to AD [137].

DNA lesions and acute oxidative stress can affect tau directly too. They change its phosphorylation state and also affect its localization. For instance, in SH-SY5Y cells, the DNA-damaging drug etoposide induces the translocation of tau to the nucleus while lowering its phosphorylation levels [115]. Although DNA damage may reduce tau phosphorylation, DDR checkpoint kinases can directly target tau. For instance, checkpoint kinase 2 (Chk2)-dependent phosphorylation of tau enhanced its toxicity in a transgenic Drosophila model [138]. Other DDR-related proteins can affect tau phosphorylation. p53 is upregulated in AD brains compared to controls and indirectly, not being a kinase, it induces phosphorylation of tau in HEK293 cells [139,140]. Although the exact function of this link is still debated, it does suggest an undefined role for tau in the cell cycle regulation of neurons undergoing neurodegenerative processes. Overall, however, how pathogenic, hyperphosphorylated and aggregated tau affects DNA lesions and their repair is not fully understood.

As reported above, tau mutations have been associated with a greater predisposition to cancer due to genomic instability [133], but a direct link with an increase in genomic instability in neurons and AD is still missing. Nevertheless, tau's interaction with DNA may be affected by both aggregation and phosphorylation $[141,142]$, reducing its putative protective function. 


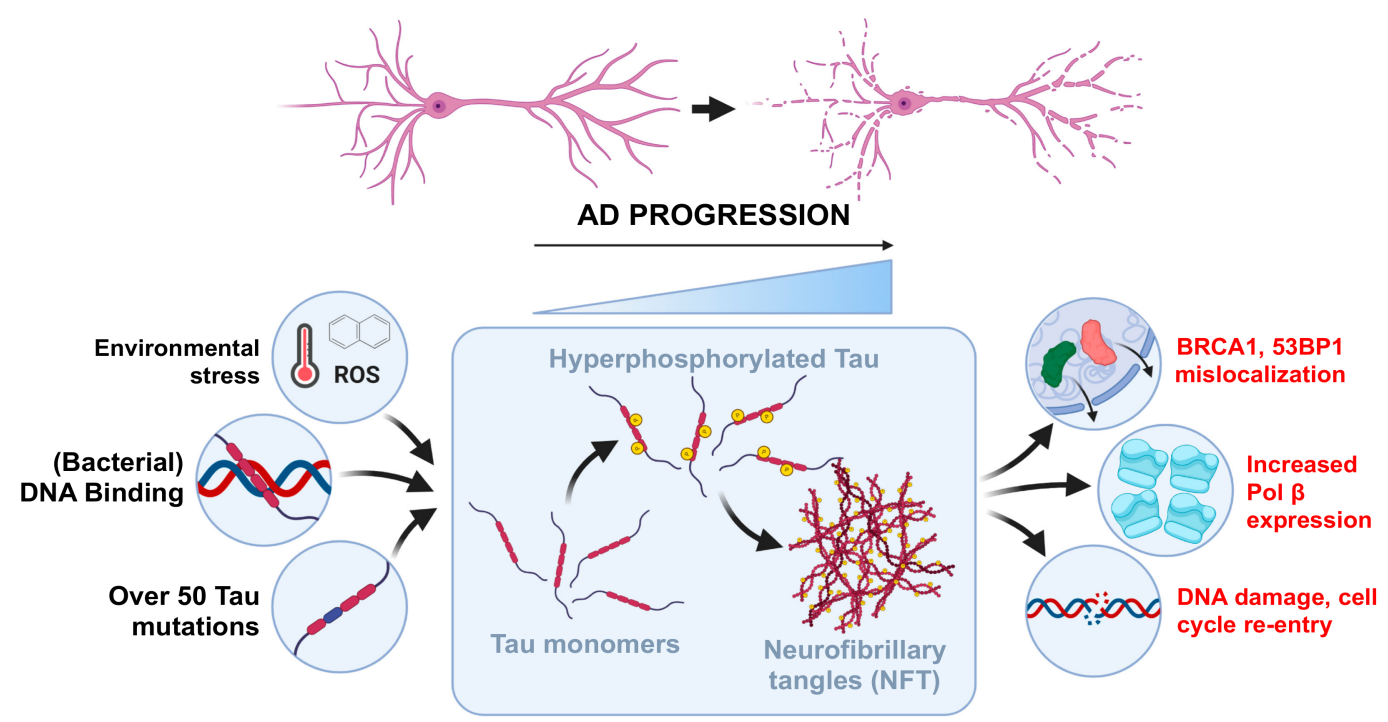

Figure 2. Tau, interaction with DNA damage and AD progression. DNA insults, such as caused by reactive oxygen species (ROS), bacterial infections and tau mutations, can cause hyperphosphorylation of tau and the formation of neurofibrillary tangles (NFT) in AD-induced progression. This particular situation drastically negatively influences DNA damages and repair pathways (Red).

In addition, DNA repair too may be altered by tau oligomers [143]. In the transgenic mouse tau model Thy-Tau22, when hippocampal neurons are enriched in tau oligomers at six months of age, Pol $\beta$ expression is elevated [144]. This is likely to be due to the increase in oxidative stress underlying the onset and progression of the disorder, and not directly to tau oligomers. More directly, however, tau oligomerization is reported to affect the localization of DDR proteins. Tau aggregation mislocalizes BRCA1 and p53-binding protein (53BP1) $[94,145]$ in the cytoplasm of neurons during AD and other tauopathies such as Pick's disease and progressive supranuclear palsy, causing its insolubility. Sequestration of BRCA1 and 53BP1 in the cytoplasm by hyperphosphorylated and aggregated tau may therefore contribute to the progression of tauopathies [94,145].

\section{Conclusions}

The connection between tau and maintenance of genome integrity has been described by several laboratories. Brain samples from AD patients exhibit neuronal death and accumulation of genomic lesions. Reports suggest that hyperphosphorylated and aggregated tau may impair DNA repair by interacting with, and sequestering to the cytoplasm, DNA repair proteins such as BRCA1. A clear link between tau, DNA damage and neurodegeneration, however, is still missing. Future experiments should investigate the role of tau hyperphosphorylation, tau aggregation and tau mutations in the formation and repair of DNA lesions described in AD neurons. DNA damage and repair pathways have been extensively studied in oncology [146], where DNA mutations are a driving force in cancer growth [40], and several drugs have been developed to target them [147]. A better understanding of the role of DNA lesions in AD could also lead to better and innovative therapeutic regimens. Besides AD, DNA lesions in other tauopathies have received less attention. Finally, loss of genomic integrity might be a common theme in a number of other neurodegenerative disorders: several proteins with the tendency to aggregate aberrantly and cause neuronal death also interact with DNA $[148,149]$. Examples are Parkinson's disease, polyglutamine diseases such as Huntington's disease, and amyotrophic lateral sclerosis $[150,151]$, suggesting, therefore, that DNA lesions and their repair may contribute to neurodegenerative processes. 
Author Contributions: Conceptualization, writing, original draft preparation, L.C., S.S.; figure preparation D.R.; review and editing, L.C., R.D., M.M.-F., S.S.; supervision and funding acquisition, L.C, M.M.-F. and S.S. All authors have read and agreed to the published version of the manuscript.

Funding: L.C. was supported by Brigthfocus Grant A2019296F and a grant from the Fondo di Beneficenza-Gruppo Intesa Sanpaolo. M.M.-F. was supported by Associazione Italiana per la Ricerca sul Cancro (AIRC), grant number IG21806, Telethon, grant number GGP15227 and MIUR grant number PRIN-2017KSZZJW_002. S.S. was supported by Finanziamento Linea 2-Università degli studi di Milano.

Conflicts of Interest: The authors declare no conflict of interests.

\section{References}

1. Przedborski, S.; Vila, M.; Jackson-Lewis, V. Series Introduction: Neurodegeneration: What is it and where are we? J. Clin. Investig. 2003, 111, 3-10. [CrossRef] [PubMed]

2. Alzheimer's Association. Alzheimer's disease facts and figures. Alzheimer's Dement. 2018, 14, 367-429. [CrossRef]

3. Binder, L.I.; Guillozet-Bongaarts, A.L.; Garcia-Sierra, F.; Berry, R.W. Tau, tangles, and Alzheimer's disease. Biochim. Biophys. Acta (BBA) Mol. Basis Dis. 2005, 1739, 216-223. [CrossRef] [PubMed]

4. Goedert, M. Tau filaments in neurodegenerative diseases. FEBS Lett. 2018, 592, $2383-2391$. [CrossRef] [PubMed]

5. Goedert, M.; Spillantini, M.G. Ordered Assembly of Tau Protein and Neurodegeneration. In Tau Biology; Takashima, A., Wolozin, B., Buee, L., Eds.; Springer: Singapore, 2019; pp. 3-21. ISBN 978-981-329-358-8.

6. Falcon, B.; Zhang, W.; Schweighauser, M.; Murzin, A.G.; Vidal, R.; Garringer, H.J.; Ghetti, B.; Scheres, S.H.W.; Goedert, M. Tau filaments from multiple cases of sporadic and inherited Alzheimer's disease adopt a common fold. Acta Neuropathol. 2018, 136, 699-708. [CrossRef] [PubMed]

7. Falcon, B.; Zivanov, J.; Zhang, W.; Murzin, A.G.; Garringer, H.J.; Vidal, R.; Crowther, R.A.; Newell, K.L.; Ghetti, B.; Goedert, M.; et al. Novel tau filament fold in chronic traumatic encephalopathy encloses hydrophobic molecules. Nature 2019, 568, 420-423. [CrossRef]

8. Zhang, W.; Tarutani, A.; Newell, K.L.; Murzin, A.G.; Matsubara, T.; Falcon, B.; Vidal, R.; Garringer, H.J.; Shi, Y.; Ikeuchi, T.; et al. Novel tau filament fold in corticobasal degeneration. Nat. Cell Biol. 2020, 580, 283-287. [CrossRef]

9. Falcon, B.; Zhang, W.; Murzin, A.G.; Murshudov, G.; Garringer, H.J.; Vidal, R.; Crowther, R.A.; Ghetti, B.; Scheres, S.H.W.; Goedert, M. Structures of filaments from Pick's disease reveal a novel tau protein fold. Nat. Cell Biol. 2018, 561, 137-140. [CrossRef]

10. Weingarten, M.D.; Lockwood, A.H.; Hwo, S.Y.; Kirschner, M.W. A protein factor essential for microtubule assembly. Proc. Natl. Acad. Sci. USA 1975, 72, 1858-1862. [CrossRef]

11. Barbier, P.; Zejneli, O.; Martinho, M.; Lasorsa, A.; Belle, V.; Smet-Nocca, C.; Tsvetkov, P.O.; Devred, F.; Landrieu, I. Role of Tau as a Microtubule-Associated Protein: Structural and Functional Aspects. Front. Aging Neurosci. 2019, 11. [CrossRef]

12. Witman, G.B.; Page, D.C.; Weingarten, M.D.; Kirschner, M.W. Tubulin requires tau for growth onto microtubule initiating sites. Proc. Natl. Acad. Sci. USA 1976, 73, 4070-4074. [CrossRef] [PubMed]

13. Kent, S.A.; Spires-Jones, T.L.; Durrant, C.S. The physiological roles of tau and A $\beta$ : Implications for Alzheimer's disease pathology and therapeutics. Acta Neuropathol. 2020, 140, 417-447. [CrossRef] [PubMed]

14. Black, M.M.; Slaughter, T.; Moshiach, S.; Obrocka, M.; Fischer, I. Tau Is Enriched on Dynamic Microtubules in the Distal Region of Growing Axons. J. Neurosci. 1996, 16, 3601-3619. [CrossRef] [PubMed]

15. Andreadis, A.; Brown, W.M.; Kosik, K.S. Structure and novel exons of the human .tau. gene. Biochemistry 1992, 31, 10626-10633. [CrossRef] [PubMed]

16. Goedert, M.; Spillantini, M.G.; Jakes, R.; Rutherford, D.; Crowther, R.A. Multiple isoforms of human microtubule-associated protein tau: Sequences and localization in neurofibrillary tangles of Alzheimer's disease. Neuron 1989, 3, 519-526. [CrossRef]

17. Buée, L.; Bussière, T.; Buée-Scherrer, V.; Delacourte, A.; Hof, P.R. Tau protein isoforms, phosphorylation and role in neurodegenerative disorders11These authors contributed equally to this work. Brain Res. Rev. 2000, 33, 95-130. [CrossRef] 
18. Gunawardana, C.G.; Mehrabian, M.; Wang, X.; Mueller, I.; Lubambo, I.B.; Jonkman, J.E.N.; Wang, H.; Schmitt-Ulms, G. The Human Tau Interactome: Binding to the Ribonucleoproteome, and Impaired Binding of the Proline-to-Leucine Mutant at Position 301 (P301L) to Chaperones and the Proteasome. Mol. Cell. Proteom. 2015, 14, 3000-3014. [CrossRef]

19. Sultan, A.; Nesslany, F.; Violet, M.; Bégard, S.; Loyens, A.; Talahari, S.; Mansuroglu, Z.; Marzin, D.; Sergeant, N.; Humez, S.; et al. Nuclear Tau, a Key Player in Neuronal DNA Protection. J. Biol. Chem. 2010, 286, 4566-4575. [CrossRef]

20. Mazanetz, M.P.; Fischer, P.M. Untangling tau hyperphosphorylation in drug design for neurodegenerative diseases. Nat. Rev. Drug Discov. 2007, 6, 464-479. [CrossRef]

21. Xia, C.; Makaretz, S.J.; Caso, C.; McGinnis, S.; Gomperts, S.N.; Sepulcre, J.; Gomez-Isla, T.; Hyman, B.T.; Schultz, A.; Vasdev, N.; et al. Association of In Vivo [18F] AV-1451 Tau PET Imaging Results with Cortical Atrophy and Symptoms in Typical and Atypical Alzheimer Disease. JAMA Neurol. 2017, 74, 427-436. [CrossRef]

22. Arriagada, P.V.; Growdon, J.H.; Hedley-Whyte, E.T.; Hyman, B.T. Neurofibrillary tangles but not senile plaques parallel duration and severity of Alzheimer's disease. Neurology 1992, 42, 631-639. [CrossRef] [PubMed]

23. Lee, H.-G.; Perry, G.; Moreira, P.I.; Garrett, M.R.; Liu, Q.; Zhu, X.; Takeda, A.; Nunomura, A.; Smith, M.A. Tau phosphorylation in Alzheimer's disease: Pathogen or protector? Trends Mol. Med. 2005, 11, 164-169. [CrossRef] [PubMed]

24. Umeda, T.; Maekawa, S.; Kimura, T.; Takashima, A.; Tomiyama, T.; Mori, H. Neurofibrillary tangle formation by introducing wild-type human tau into APP transgenic mice. Acta Neuropathol. 2014, 127, 685-698. [CrossRef] [PubMed]

25. Hasegawa, M.; Smith, M.J.; Goedert, M. Tau proteins with FTDP-17 mutations have a reduced ability to promote microtubule assembly. FEBS Lett. 1998, 437, 207-210. [CrossRef]

26. Barghorn, S.; Zheng-Fischhöfer, Q.; Ackmann, M.; Biernat, J.; Von Bergen, M.; Mandelkow, E.-M.; Mandelkow, E. Structure, Microtubule Interactions, and Paired Helical Filament Aggregation by Tau Mutants of Frontotemporal Dementias. Biochemistry 2000, 39, 11714-11721. [CrossRef] [PubMed]

27. Ross, C.A.; Poirier, M.A. Protein aggregation and neurodegenerative disease. Nat. Med. 2004, 10, S10-S17. [CrossRef] [PubMed]

28. Takalo, M.; Salminen, A.; Soininen, H.; Hiltunen, M.; Haapasalo, A. Protein aggregation and degradation mechanisms in neurodegenerative diseases. Am. J. Neurodegener. Dis. 2013, 2, 1-14.

29. Bittar, A.; Bhatt, N.; Kayed, R. Advances and considerations in AD tau-targeted immunotherapy. Neurobiol. Dis. 2020, 134, 104707. [CrossRef]

30. Castillo-Carranza, D.L.; Gerson, J.E.; Sengupta, U.; Guerrero-Muñoz, M.J.; Lasagna-Reeves, C.A.; Kayed, R. Specific Targeting of Tau Oligomers in Htau Mice Prevents Cognitive Impairment and Tau Toxicity Following Injection with Brain-Derived Tau Oligomeric Seeds. J. Alzheimer's Dis. 2014, 40, S97-S111. [CrossRef]

31. Murphy, M.P.; Levine, H. Alzheimer's Disease and the Amyloid- $\beta$ Peptide. J. Alzheimer's Dis. 2010, 19, 311. [CrossRef]

32. Sevigny, J.; Chiao, P.; Bussière, T.; Weinreb, P.H.; Williams, L.; Maier, M.; Dunstan, R.; Salloway, S.; Chen, T.; Ling, Y.; et al. The antibody aducanumab reduces $A \beta$ plaques in Alzheimer's disease. Nature 2016, 537, 50-56. [CrossRef] [PubMed]

33. Schneider, L. A resurrection of aducanumab for Alzheimer's disease. Lancet Neurol. 2020, 19, 111-112. [CrossRef]

34. Martin, L.; Latypova, X.; Terro, F. Post-translational modifications of tau protein: Implications for Alzheimer's disease. Neurochem. Int. 2011, 58, 458-471. [CrossRef] [PubMed]

35. Ittner, L.M.; Ke, Y.D.; Delerue, F.; Bi, M.; Gladbach, A.; Van Eersel, J.; Wölfing, H.; Chieng, B.C.; Christie, M.J.; Napier, I.A.; et al. Dendritic Function of Tau Mediates Amyloid- $\beta$ Toxicity in Alzheimer's Disease Mouse Models. Cell 2010, 142, 387-397. [CrossRef] [PubMed]

36. Ward, S.M.; Himmelstein, D.S.; Lancia, J.K.; Binder, L.I. Tau oligomers and tau toxicity in neurodegenerative disease. Biochem. Soc. Trans. 2012, 40, 667-671. [CrossRef]

37. Rady, R.M.; Zinkowski, R.P.; Binder, L.I. Presence of tau in isolated nuclei from human brain. Neurobiol. Aging 1995, 16, 479-486. [CrossRef]

38. Madabhushi, R.; Pan, L.; Tsai, L.-H. DNA Damage and Its Links to Neurodegeneration. Neuron 2014, 83, 266-282. [CrossRef] 
39. Adamec, E.; Vonsattel, J.P.; Nixon, R.A. DNA strand breaks in Alzheimer's disease. Brain Res. 1999, 849, 67-77. [CrossRef]

40. Negrini, S.; Gorgoulis, V.G.; Halazonetis, T.D. Genomic instability—An evolving hallmark of cancer. Nat. Rev. Mol. Cell Biol. 2010, 11, 220-228. [CrossRef]

41. Chatterjee, N.; Walker, G.C. Mechanisms of DNA damage, repair, and mutagenesis. Environ. Mol. Mutagen. 2017, 58, 235-263. [CrossRef]

42. Turgeon, M.-O.; Perry, N.J.S.; Poulogiannis, G. DNA Damage, Repair, and Cancer Metabolism. Front. Oncol. 2018, 8. [CrossRef] [PubMed]

43. Jackson, S.D.; Bartek, J. The DNA-damage response in human biology and disease. Nat. Cell Biol. 2009, 461, 1071-1078. [CrossRef] [PubMed]

44. Bermúdez-Guzmán, L.; Leal, A. DNA repair deficiency in neuropathogenesis: When all roads lead to mitochondria. Transl. Neurodegener. 2019, 8, 14. [CrossRef]

45. Knoch, J.; Kamenisch, Y.; Kubisch, C.; Berneburg, M. Rare hereditary diseases with defects in DNA-repair. Eur. J. Dermatol. EJD 2012, 22, 443-455. [CrossRef] [PubMed]

46. Friedberg, E.C. DNA damage and repair. Nat. Cell Biol. 2003, 421, 436-440. [CrossRef]

47. Sancar, A.; Lindsey-Boltz, L.A.; Ünsal-Kaçmaz, K.; Linn, S. Molecular Mechanisms of Mammalian DNA Repair and the DNA Damage Checkpoints. Annu. Rev. Biochem. 2004, 73, 39-85. [CrossRef]

48. Krokan, H.E.; Bjørås, M. Base Excision Repair. Cold Spring Harb. Perspect. Biol. 2013, 5. [CrossRef]

49. Li, G.-M. Mechanisms and functions of DNA mismatch repair. Cell Res. 2008, 18, 85-98. [CrossRef]

50. Schaerer, O.D. Nucleotide Excision Repair in Eukaryotes. Cold Spring Harb. Perspect. Biol. 2013, 5. [CrossRef]

51. Chapman, J.R.; Taylor, M.R.; Boulton, S.J. Playing the End Game: DNA Double-Strand Break Repair Pathway Choice. Mol. Cell 2012, 47, 497-510. [CrossRef]

52. Khanna, K.K.; Jackson, S.P. DNA double-strand breaks: Signaling, repair and the cancer connection. Nat. Genet. 2001, 27, 247-254. [CrossRef] [PubMed]

53. Wright, W.D.; Shah, S.S.; Heyer, W.-D. Homologous recombination and the repair of DNA double-strand breaks. J. Biol. Chem. 2018, 293, 10524-10535. [CrossRef] [PubMed]

54. Chang, H.H.Y.; Pannunzio, N.R.; Adachi, N.; Lieber, M.R. Non-homologous DNA end joining and alternative pathways to double-strand break repair. Nat. Rev. Mol. Cell Biol. 2017, 18, 495-506. [CrossRef]

55. McMurray, C.T. To die or not to die: DNA repair in neurons. Mutat. Res. Mol. Mech. Mutagen. 2005, 577, 260-274. [CrossRef] [PubMed]

56. Wei, W.; Englander, E.W. DNA polymerase $\beta$-catalyzed-PCNA independent long patch base excision repair synthesis: A mechanism for repair of oxidatively damaged DNA ends in post-mitotic brain. J. Neurochem. 2008, 107, 734-744. [CrossRef]

57. Akbari, M.; Pena-Diaz, J.; Andersen, S.; Liabakk, N.-B.; Otterlei, M.; Krokan, H.E. Extracts of proliferating and non-proliferating human cells display different base excision pathways and repair fidelity. DNA Repair 2009, 8, 834-843. [CrossRef]

58. Frade, J.M.; Ovejero-Benito, M.C. Neuronal cell cycle: The neuron itself and its circumstances. Cell Cycle 2015, 14, 712-720. [CrossRef]

59. Narciso, L.; Parlanti, E.; Racaniello, M.; Simonelli, V.; Cardinale, A.; Merlo, D.; Dogliotti, E. The Response to Oxidative DNA Damage in Neurons: Mechanisms and Disease. Neural Plast. 2016, 2016, 361927. [CrossRef]

60. Suberbielle, E.; Sanchez, P.E.; Kravitz, A.V.; Wang, X.; Ho, K.; Eilertson, K.; Devidze, N.; Kreitzer, A.C.; Mucke, L. Physiologic brain activity causes DNA double-strand breaks in neurons, with exacerbation by amyloid- $\beta$. Nat. Neurosci. 2013, 16, 613-621. [CrossRef]

61. Zlokovic, B.V. The Blood-Brain Barrier in Health and Chronic Neurodegenerative Disorders. Neuron 2008, 57, 178-201. [CrossRef]

62. Das, M.; Seth, P.K.; Mukhtar, H. Distribution of benzo(a)pyrene in discrete regions of rat brain. Bull. Environ. Contam. Toxicol. 1985, 35, 500-504. [CrossRef] [PubMed]

63. Watts, M.E.; Pocock, R.; Claudianos, C. Brain Energy and Oxygen Metabolism: Emerging Role in Normal Function and Disease. Front. Mol. Neurosci. 2018, 11. [CrossRef] [PubMed]

64. Madabhushi, R.; Gao, F.; Pfenning, A.R.; Pan, L.; Yamakawa, S.; Seo, J.; Rueda, R.; Phan, T.X.; Yamakawa, H.; Pao, P.-C.; et al. Activity-Induced DNA Breaks Govern the Expression of Neuronal Early-Response Genes. Cell 2015, 161, 1592-1605. [CrossRef] [PubMed] 
65. Uematsu, N.; Weterings, E.; Yano, K.; Morotomi-Yano, K.; Jakob, B.; Taucher-Scholz, G.; Mari, P.-O.; Van Gent, D.C.; Chen, B.P.C.; Chen, D.J. Autophosphorylation of DNA-PKCS regulates its dynamics at DNA double-strand breaks. J. Cell Biol. 2007, 177, 219-229. [CrossRef] [PubMed]

66. Dobbs, T.A.; Tainer, J.A.; Lees-Miller, S.P. A structural model for regulation of NHEJ by DNA-PKcs autophosphorylation. DNA Repair 2010, 9, 1307-1314. [CrossRef] [PubMed]

67. Culmsee, C.; Bondada, S.; Mattson, M.P. Hippocampal neurons of mice deficient in DNA-dependent protein kinase exhibit increased vulnerability to DNA damage, oxidative stress and excitotoxicity. Mol. Brain Res. 2001, 87, 257-262. [CrossRef]

68. Zada, D.; Bronshtein, I.; Lerer-Goldshtein, T.; Garini, Y.; Appelbaum, L. Sleep increases chromosome dynamics to enable reduction of accumulating DNA damage in single neurons. Nat. Commun. 2019, 10, 1-12. [CrossRef]

69. Bellesi, M.; Bushey, D.; Chini, M.; Tononi, G.; Cirelli, C. Contribution of sleep to the repair of neuronal DNA double-strand breaks: Evidence from flies and mice. Sci. Rep. 2016, 6, 1-13. [CrossRef]

70. McKinnon, P.J. DNA repair deficiency and neurological disease. Nat. Rev. Neurosci. 2009, 10, 100-112. [CrossRef]

71. Lodato, M.A.; Woodworth, M.B.; Lee, S.; Evrony, G.D.; Mehta, B.K.; Karger, A.; Lee, S.; Chittenden, T.W.; D'Gama, A.M.; Cai, X.; et al. Somatic mutation in single human neurons tracks developmental and transcriptional history. Science 2015, 350, 94-98. [CrossRef]

72. Lodato, M.A.; Rodin, R.E.; Bohrson, C.L.; Coulter, M.E.; Barton, A.R.; Kwon, M.; Sherman, M.A.; Vitzthum, C.M.; Luquette, L.J.; Yandava, C.N.; et al. Aging and neurodegeneration are associated with increased mutations in single human neurons. Science 2018, 359, 555-559. [CrossRef] [PubMed]

73. Goedert, M.; Spillantini, M.G. A Century of Alzheimer's Disease. Science 2006, 314, $777-781$. [CrossRef] [PubMed]

74. Thadathil, N.; Delotterie, D.F.; Xiao, J.; Hori, R.; McDonald, M.P.; Khan, M.M. DNA Double-Strand Break Accumulation in Alzheimer's Disease: Evidence from Experimental Models and Postmortem Human Brains. Mol. Neurobiol. 2021, 58, 118-131. [CrossRef] [PubMed]

75. Stadelmann, C.; Brück, W.; Bancher, C.; Jellinger, K.; Lassmann, H. Alzheimer Disease. J. Neuropathol. Exp. Neurol. 1998, 57, 456-464. [CrossRef] [PubMed]

76. Anderson, A.; Su, J.; Cotman, C. DNA damage and apoptosis in Alzheimer's disease: Colocalization with c- Jun immunoreactivity, relationship to brain area, and effect of postmortem delay. J. Neurosci. Off. J. Soc. Neurosci. 1996, 16, 1710-1719. [CrossRef]

77. Khurana, V.; Merlo, P.; DuBoff, B.; Fulga, T.A.; Sharp, K.A.; Campbell, S.D.; Götz, J.; Feany, M.B. A neuroprotective role for the DNA damage checkpoint in tauopathy. Aging Cell 2012, 11, 360-362. [CrossRef] [PubMed]

78. Mullaart, E.; Boerrigter, M.E.; Ravid, R.; Swaab, D.F.; Vijg, J. Increased levels of DNA breaks in cerebral cortex of Alzheimer's disease patients. Neurobiol. Aging 1990, 11, 169-173. [CrossRef]

79. Katsel, P.; Tan, W.; Fam, P.; Purohit, D.P.; Haroutunian, V. Cycle Checkpoint Abnormalities during Dementia: A Plausible Association with the Loss of Protection against Oxidative Stress in Alzheimer's Disease. PLoS ONE 2013, 8. [CrossRef]

80. Shen, X.; Chen, J.; Li, J.; Kofler, J.; Herrup, K. Neurons in Vulnerable Regions of the Alzheimer's Disease Brain Display Reduced ATM Signaling. eNeuro 2016, 3. [CrossRef]

81. Shanbhag, N.M.; Evans, M.D.; Mao, W.; Nana, A.L.; Seeley, W.W.; Adame, A.; Rissman, R.A.; Masliah, E.; Mucke, L. Early neuronal accumulation of DNA double strand breaks in Alzheimer's disease. Acta Neuropathol. Commun. 2019, 7, 77. [CrossRef]

82. Gauthier, S.; Reisberg, B.; Zaudig, M.; Petersen, R.C.; Ritchie, K.; Broich, K.; Belleville, S.; Brodaty, H.; Bennett, D.; Chertkow, H.; et al. Mild cognitive impairment. Lancet 2006, 367, 1262-1270. [CrossRef]

83. Lyras, L.; Cairns, N.J.; Jenner, A.; Jenner, P.; Halliwell, B. An Assessment of Oxidative Damage to Proteins, Lipids, and DNA in Brain from Patients with Alzheimer's Disease. J. Neurochem. 2002, 68, 2061-2069. [CrossRef] [PubMed]

84. Good, P.F.; Werner, P.; Hsu, A.; Olanow, C.W.; Perl, D.P. Evidence of neuronal oxidative damage in Alzheimer's disease. Am. J. Pathol. 1996, 149, 21-28. [PubMed]

85. Mecocci, P.; MacGarvey, U.; Beal, M.F. Oxidative damage to mitochondrial DNA is increased in Alzheimer's disease. Ann. Neurol. 1994, 36, 747-751. [CrossRef] 
86. Weissman, L.; Jo, D.-G.; Sørensen, M.M.; De Souza-Pinto, N.C.; Markesbery, W.R.; Mattson, M.P.; Bohr, V.A. Defective DNA base excision repair in brain from individuals with Alzheimer's disease and amnestic mild cognitive impairment. Nucleic Acids Res. 2007, 35, 5545-5555. [CrossRef]

87. Davydov, V.; Hansen, L.A.; Shackelford, D.A. Is DNA repair compromised in Alzheimer's disease? Neurobiol. Aging 2003, 24, 953-968. [CrossRef]

88. Shackelford, D.A. DNA end joining activity is reduced in Alzheimer's disease. Neurobiol. Aging 2006, 27, 596-605. [CrossRef]

89. Cardinale, A.; Racaniello, M.; Saladini, S.; De Chiara, G.; Mollinari, C.; De Stefano, M.C.; Pocchiari, M.; Garaci, E.; Merlo, D. Sublethal Doses of $\beta$-Amyloid Peptide Abrogate DNA-dependent Protein Kinase Activity. J. Biol. Chem. 2012, 287, 2618-2631. [CrossRef]

90. Suberbielle, E.; Djukic, B.; Evans, M.; Kim, D.H.; Taneja, P.; Wang, X.; Finucane, M.; Knox, J.; Ho, K.; Devidze, N.; et al. DNA repair factor BRCA1 depletion occurs in Alzheimer brains and impairs cognitive function in mice. Nat. Commun. 2015, 6, 1-14. [CrossRef]

91. Wezyk, M.; Szybińska, A.; Wojsiat, J.; Szczerba, M.; Day, K.; Rönnholm, H.; Kele, M.; Berdynski, M.; Pepłońska, B.; Fichna, J.P.; et al. Overactive BRCA1 Affects Presenilin 1 in Induced Pluripotent Stem Cell-Derived Neurons in Alzheimer's Disease. J. Alzheimer's Dis. 2018, 62, 175-202. [CrossRef]

92. Mano, T.; Nagata, K.; Nonaka, T.; Tarutani, A.; Imamura, T.; Hashimoto, T.; Bannai, T.; Koshi-Mano, K.; Tsuchida, T.; Ohtomo, R.; et al. Neuron-specific methylome analysis reveals epigenetic regulation and tau-related dysfunction of BRCA1 in Alzheimer's disease. Proc. Natl. Acad. Sci. USA 2017, 114, E9645-E9654. [CrossRef] [PubMed]

93. Sun, L.; Zhou, R.; Yang, G.; Shi, Y. Analysis of 138 pathogenic mutations in presenilin-1 on the in vitro production of A $\beta 42$ and A $\beta 40$ peptides by $\gamma$-secretase. Proc. Natl. Acad. Sci. USA 2017, 114, E476-E485. [CrossRef] [PubMed]

94. Nakamura, M.; Kaneko, S.; Dickson, D.W.; Kusaka, H. Aberrant Accumulation of BRCA1 in Alzheimer Disease and Other Tauopathies. J. Neuropathol. Exp. Neurol. 2019, 79, 22-33. [CrossRef] [PubMed]

95. Liu, D.X.; Greene, L.A. Neuronal apoptosis at the G1/S cell cycle checkpoint. Cell Tissue Res. 2001, 305, 217-228. [CrossRef]

96. Currais, A.; Hortobágyi, T.; Soriano, S. The neuronal cell cycle as a mechanism of pathogenesis in Alzheimer's disease. Aging 2009, 1, 363-371. [CrossRef]

97. Herrup, K.; Yang, Y. Cell cycle regulation in the postmitotic neuron: Oxymoron or new biology? Nat. Rev. Neurosci. 2007, 8, 368-378. [CrossRef]

98. Lapham, L.W. Tetraploid DNA Content of Purkinje Neurons of Human Cerebellar Cortex. Science 1968, 159, 310-312. [CrossRef]

99. Morillo, S.M.; Escoll, P.; De La Hera, A.; Frade, J.M. Somatic tetraploidy in specific chick retinal ganglion cells induced by nerve growth factor. Proc. Natl. Acad. Sci. USA 2009, 107, 109-114. [CrossRef]

100. Yang, Y.; Geldmacher, D.S.; Herrup, K. DNA Replication Precedes Neuronal Cell Death in Alzheimer's Disease. J. Neurosci. 2001, 21, 2661-2668. [CrossRef]

101. Mosch, B.; Morawski, M.; Mittag, A.; Lenz, D.; Tárnok, A.; Arendt, T. Aneuploidy and DNA Replication in the Normal Human Brain and Alzheimer's Disease. J. Neurosci. Off. J. Soc. Neurosci. 2007, 27, 6859-6867. [CrossRef]

102. Sharma, R.; Kumar, D.; Jha, N.K.; Jha, S.K.; Ambasta, R.K.; Kumar, P. Re-expression of cell cycle markers in aged neurons and muscles: Whether cells should divide or die? Biochim. Biophys. Acta BBA Mol. Basis Dis. 2017, 1863, 324-336. [CrossRef] [PubMed]

103. Zhu, X.; McShea, A.; Harris, P.L.; Raina, A.K.; Castellani, R.J.; Funk, J.O.; Shah, S.; Atwood, C.; Bowen, R.; Bowser, R.; et al. Elevated expression of a regulator of the G2/M phase of the cell cycle, neuronal CIP-1-associated regulator of cyclin B, in Alzheimer's disease. J. Neurosci. Res. 2004, 75, 698-703. [CrossRef] [PubMed]

104. Walton, C.C.; Zhang, W.; Patiño-Parrado, I.; Barrio-Alonso, E.; Garrido, J.-J.; Frade, J.M. Primary neurons can enter M-phase. Sci. Rep. 2019, 9, 1-15. [CrossRef] [PubMed]

105. Bowser, R.; Smith, M.A. Cell cycle proteins in Alzheimer's disease: Plenty of wheels but no cycle. J. Alzheimer's Dis. 2002, 4, 249-254. [CrossRef] 
106. Kruman, I.I.; Wersto, R.P.; Cardozo-Pelaez, F.; Smilenov, L.; Chan, S.L.; Chrest, F.J.; Emokpae, R.; Gorospe, M.; Mattson, M.P. Cell Cycle Activation Linked to Neuronal Cell Death Initiated by DNA Damage. Neuron 2004, 41, 549-561. [CrossRef]

107. Ding, X.-L.; Husseman, J.; Tomashevski, A.; Nochlin, D.; Jin, L.-W.; Vincent, I. The Cell Cycle Cdc25A Tyrosine Phosphatase Is Activated in Degenerating Postmitotic Neurons in Alzheimer's Disease. Am. J. Pathol. 2000, 157, 1983-1990. [CrossRef]

108. Bonda, D.J.; Bajić, V.P.; Spremo-Potparevic, B.; Casadesus, G.; Zhu, X.; Smith, M.A.; Lee, H.-G. Review: Cell cycle aberrations and neurodegeneration. Neuropathol. Appl. Neurobiol. 2010, 36, 157-163. [CrossRef]

109. López-Sánchez, N.; Fontán-Lozano, Á.; Pallé, A.; González-Álvarez, V.; Rábano, A.; Trejo, J.L.; Frade, J.M. Neuronal tetraploidization in the cerebral cortex correlates with reduced cognition in mice and precedes and recapitulates Alzheimer's-associated neuropathology. Neurobiol. Aging 2017, 56, 50-66. [CrossRef]

110. Sanphui, P.; Pramanik, S.K.; Chatterjee, N.; Moorthi, P.; Banerji, B.; Biswas, S.C. Efficacy of Cyclin Dependent Kinase 4 Inhibitors as Potent Neuroprotective Agents against Insults Relevant to Alzheimer's Disease. PLoS ONE 2013, 8, e78842. [CrossRef]

111. Lu, J.; Li, T.; He, R.; Bartlett, P.F.; Götz, J. Visualizing the microtubule-associated protein tau in the nucleus. Sci. China Life Sci. 2014, 57, 422-431. [CrossRef]

112. Greenwood, J.A.; Johnson, G.V. Localization and in Situ Phosphorylation State of Nuclear Tau. Exp. Cell Res. 1995, 220, 332-337. [CrossRef] [PubMed]

113. Frost, B.; Hemberg, M.; Lewis, J.; Feany, M.B. Tau promotes neurodegeneration through global chromatin relaxation. Nat. Neurosci. 2014, 17, 357-366. [CrossRef] [PubMed]

114. Bukar, M.; Al-Hilaly, Y.K.; Serpell, L.C. Nuclear Tau and Its Potential Role in Alzheimer's Disease. Biomolecules 2016, 6, 9. [CrossRef] [PubMed]

115. Ulrich, G.; Salvadè, A.; Boersema, P.; Calì, T.; Foglieni, C.; Sola, M.; Picotti, P.; Papin, S.; Paganetti, P. Phosphorylation of nuclear Tau is modulated by distinct cellular pathways. Sci. Rep. 2018, 8, 1-14. [CrossRef] [PubMed]

116. Hua, Q.; He, R. Tau could protect DNA double helix structure. Biochim. Biophys. Acta BBA Proteins Proteom. 2003, 1645, 205-211. [CrossRef]

117. Hua, Q.; He, R.-Q.; Haque, N.; Qu, M.-H.; Alonso, A.; Grundke-Iqbal, I.; Iqbal, K. Microtubule associated protein tau binds to double-stranded but not single-stranded DNA. Cell. Mol. Life Sci. 2003, 60, 413-421. [CrossRef]

118. Lu, Y.; He, H.-J.; Zhou, J.; Miao, J.-Y.; Lu, J.; He, Y.-G.; Pan, R.; Wei, Y.; Liu, Y.; He, R.Q. Hyperphosphorylation Results in Tau Dysfunction in DNA Folding and Protection. J. Alzheimer's Dis. 2013, 37, 551-563. [CrossRef]

119. Gorces, V.G.; Manso, R.; Torre, J.D.L.; Avila, J.; Nasr, A.; Wiche, G. Effects of DNA on Microtubule Assembly. J. Biol. Inorg. Chem. 1980, 105, 7-16. [CrossRef]

120. Camero, S.; Benítez, M.J.; Barrantes, A.; Ayuso, J.M.; Cuadros, R.; Ávila, J.; Jiménez, J.S. Tau Protein Provides DNA with Thermodynamic and Structural Features which are Similar to those Found in Histone-DNA Complex. J. Alzheimer's Dis. 2014, 39, 649-660. [CrossRef]

121. Ljungman, M.; Hanawalt, P.C. Efficient protection against oxidative DNA damage in chromatin. Mol. Carcinog. 1992, 5, 264-269. [CrossRef]

122. Hua, Q.; He, R. Human neuronal tau promoting the melting temperature of DNA. Chin. Sci. Bull. 2000, 45, 999-1002. [CrossRef]

123. Silva, J.L.; Cordeiro, Y. The "Jekyll and Hyde" Actions of Nucleic Acids on the Prion-like Aggregation of Proteins. J. Biol. Chem. 2016, 291, 15482-15490. [CrossRef] [PubMed]

124. Tetz, G.; Pinho, M.; Pritzkow, S.; Mendez, N.; Soto, C.; Tetz, V. Bacterial DNA promotes Tau aggregation. Sci. Rep. 2020, 10, 2369. [CrossRef] [PubMed]

125. Maheshwari, P.; Eslick, G.D. Bacterial Infection and Alzheimer's Disease: A Meta-Analysis. J. Alzheimer's Dis. 2014, 43, 957-966. [CrossRef]

126. Bulgart, H.R.; Neczypor, E.W.; Wold, L.E.; Mackos, A.R. Microbial involvement in Alzheimer disease development and progression. Mol. Neurodegener. 2020, 15, 4. [CrossRef]

127. Álvarez, G.; Aldudo, J.; Alonso, M.; Santana, S.; Valdivieso, F. Herpes simplex virus type 1 induces nuclear accumulation of hyperphosphorylated tau in neuronal cells. J. Neurosci. Res. 2012, 90, 1020-1029. [CrossRef] 
128. Benhelli-Mokrani, H.; Mansuroglu, Z.; Chauderlier, A.; Albaud, B.; Gentien, D.; Sommer, S.; Schirmer, C.; Laqueuvre, L.; Josse, T.; Buée, L.; et al. Genome-wide identification of genic and intergenic neuronal DNA regions bound by Tau protein under physiological and stress conditions. Nucleic Acids Res. 2018, 46, 11405-11422. [CrossRef]

129. Violet, M.; Delattre, L.; Tardivel, M.; Sultan, A.; Chauderlier, A.; Caillierez, R.; Talahari, S.; Nesslany, F.; Lefebvre, B.; Bonnefoy, E.; et al. A major role for Tau in neuronal DNA and RNA protection in vivo under physiological and hyperthermic conditions. Front. Cell. Neurosci. 2014, 8. [CrossRef]

130. Bruskov, V.I.; Malakhova, L.V.; Masalimov, Z.K.; Chernikov, A.V. Heat-induced formation of reactive oxygen species and 8-oxoguanine, a biomarker of damage to DNA. Nucleic Acids Res. 2002, 30, 1354-1363. [CrossRef]

131. Rossi, G.; Dalprà, L.; Crosti, F.; Lissoni, S.; Sciacca, F.L.; Catania, M.; Mangieri, M.; Giaccone, G.; Croci, D.; Tagliavini, F. A new function of microtubule-associated protein tau: Involvement in chromosome stability. Cell Cycle 2008, 7, 1788-1794. [CrossRef]

132. Austin, K.M.; Gupta, M.L.; Coats, S.A.; Tulpule, A.; Mostoslavsky, G.; Balazs, A.B.; Mulligan, R.C.; Daley, G.; Pellman, D.; Shimamura, A. Mitotic spindle destabilization and genomic instability in Shwachman-Diamond syndrome. J. Clin. Investig. 2008, 118, 1511-1518. [CrossRef] [PubMed]

133. Rossi, G.; Redaelli, V.; Contiero, P.; Fabiano, S.; Tagliabue, G.; Perego, P.; Benussi, L.; Bruni, A.C.; Filippini, G.; Farinotti, M.; et al. Tau Mutations Serve as a Novel Risk Factor for Cancer. Cancer Res. 2018, 78, 3731-3739. [CrossRef] [PubMed]

134. Papin, S.; Paganetti, P. Emerging Evidences for an Implication of the Neurodegeneration-Associated Protein TAU in Cancer. Brain Sci. 2020, 10, 862. [CrossRef] [PubMed]

135. Maina, M.B.; Bailey, L.J.; Wagih, S.; Biasetti, L.; Pollack, S.J.; Quinn, J.P.; Thorpe, J.R.; Doherty, A.J.; Serpell, L.C. The involvement of tau in nucleolar transcription and the stress response. Acta Neuropathol. Commun. 2018, 6,1-13. [CrossRef] [PubMed]

136. Mansuroglu, Z.; Benhelli-Mokrani, H.; Marcato, V.; Sultan, A.; Violet, M.; Chauderlier, A.; Delattre, L.; Loyens, A.; Talahari, S.; Bégard, S.; et al. Loss of Tau protein affects the structure, transcription and repair of neuronal pericentromeric heterochromatin. Sci. Rep. 2016, 6, 33047. [CrossRef]

137. Baquero, J.; Varriano, S.; Ordonez, M.; Kuczaj, P.; Murphy, M.R.; Aruggoda, G.; Lundine, D.; Morozova, V.; Makki, A.E.; Alonso, A.D.; et al. Nuclear Tau, p53 and Pin1 Regulate PARN-Mediated Deadenylation and Gene Expression. Front. Mol. Neurosci. 2019, 12. [CrossRef]

138. Iijima-Ando, K.; Zhao, L.; Gatt, A.; Shenton, C.; Iijima, K. A DNA damage-activated checkpoint kinase phosphorylates tau and enhances tau-induced neurodegeneration. Hum. Mol. Genet. 2010, 19, 1930-1938. [CrossRef]

139. Hooper, C.; Meimaridou, E.; Tavassoli, M.; Melino, G.; Lovestone, S.; Killick, R. p53 is upregulated in Alzheimer's disease and induces tau phosphorylation in HEK293a cells. Neurosci. Lett. 2007, 418, 34-37. [CrossRef]

140. Jembrek, M.J.; Slade, N.; Hof, P.R.; Šimić, G. The interactions of p53 with tau and Aß as potential therapeutic targets for Alzheimer's disease. Prog. Neurobiol. 2018, 168, 104-127. [CrossRef]

141. Hua, Q.; He, R.-Q. Effect of Phosphorylation and Aggregation on Tau Binding to DNA. Available online: https: //www.ingentaconnect.com/content/ben/ppl/2002/00000009/00000004/art00011 (accessed on 17 April 2020).

142. Qi, H.; Cantrelle, F.-X.; Benhelli-Mokrani, H.; Smet-Nocca, C.; Buée, L.; Lippens, G.; Bonnefoy, E.; Galas, M.-C.; Landrieu, I. Nuclear Magnetic Resonance Spectroscopy Characterization of Interaction of Tau with DNA and Its Regulation by Phosphorylation. Biochemistry 2015, 54, 1525-1533. [CrossRef]

143. Eviolet, M.; Echauderlier, A.; Edelattre, L.; Etardivel, M.; Chouala, M.S.; Esultan, A.; Marciniak, E.; Humez, S.; Binder, L.; Kayed, R.; et al. Prefibrillar Tau oligomers alter the nucleic acid protective function of Tau in hippocampal neurons in vivo. Neurobiol. Dis. 2015, 82, 540-551. [CrossRef] [PubMed]

144. Zheng, J.; Akbari, M.; Schirmer, C.; Reynaert, M.-L.; Loyens, A.; Lefebvre, B.; Buée, L.; Croteau, D.L.; Galas, M.-C.; Bohr, V.A. Hippocampal tau oligomerization early in tau pathology coincides with a transient alteration of mitochondrial homeostasis and DNA repair in a mouse model of tauopathy. Acta Neuropathol. Commun. 2020, 8, 25. [CrossRef] [PubMed]

145. Kurihara, M.; Mano, T.; Saito, Y.; Murayama, S.; Toda, T.; Iwata, A. Colocalization of BRCA1 with Tau Aggregates in Human Tauopathies. Brain Sci. 2020, 10, 7. [CrossRef]

146. Hoeijmakers, J.H.J. DNA Damage, Aging, and Cancer. N. Engl. J. Med. 2009, 361, 1475-1485. [CrossRef] [PubMed] 
147. Gavande, N.S.; Vander Vere-Carozza, P.S.; Hinshaw, H.D.; Jalal, S.I.; Sears, C.R.; Pawelczak, K.S.; Turchi, J.J. DNA repair targeted therapy: The past or future of cancer treatment? Pharmacol. Ther. 2016, 160, 65-83. [CrossRef] [PubMed]

148. Schaser, A.J.; Osterberg, V.R.; Dent, S.E.; Stackhouse, T.L.; Wakeham, C.M.; Boutros, S.W.; Weston, L.J.; Owen, N.; Weissman, T.A.; Luna, E.; et al. Alpha-synuclein is a DNA binding protein that modulates DNA repair with implications for Lewy body disorders. Sci. Rep. 2019, 9, 1-19. [CrossRef] [PubMed]

149. Warraich, S.T.; Yang, S.; Nicholson, G.A.; Blair, I.P. TDP-43: A DNA and RNA binding protein with roles in neurodegenerative diseases. Int. J. Biochem. Cell Biol. 2010, 42, 1606-1609. [CrossRef] [PubMed]

150. Benn, C.L.; Sun, T.; Sadri-Vakili, G.; McFarland, K.N.; DiRocco, D.P.; Yohrling, G.J.; Clark, T.W.; Bouzou, B.; Cha, J.-H.J. Huntingtin modulates transcription, occupies gene promoters in vivo, and binds directly to DNA in a polyglutamine-dependent manner. J. Neurosci. Off. J. Soc. Neurosci. 2008, 28, 10720-10733. [CrossRef]

151. Mitra, J.; Guerrero, E.N.; Hegde, P.M.; Liachko, N.F.; Wang, H.; Vasquez, V.; Gao, J.; Pandey, A.; Taylor, J.P.; Kraemer, B.C.; et al. Motor neuron disease-associated loss of nuclear TDP-43 is linked to DNA double-strand break repair defects. Proc. Natl. Acad. Sci. USA 2019, 116, 4696-4705. [CrossRef]

Publisher's Note: MDPI stays neutral with regard to jurisdictional claims in published maps and institutional affiliations.

(C) 2020 by the authors. Licensee MDPI, Basel, Switzerland. This article is an open access article distributed under the terms and conditions of the Creative Commons Attribution (CC BY) license (http://creativecommons.org/licenses/by/4.0/). 